\title{
Cyclic AMP triggers glucagon-like peptide-1 secretion from the GLUTag enteroendocrine cell line
}

\author{
A. K. Simpson • P. S. Ward • K. Y. Wong • \\ G. J. Collord • A. M. Habib • F. Reimann • F. M. Gribble
}

Received: 4 April 2007 / Accepted: 30 May 2007 /Published online: 21 July 2007

(C) Springer-Verlag 2007

\begin{abstract}
Aims/hypothesis To investigate the pathways by which cyclic AMP (cAMP) stimulates glucagon-like peptide-1 (GLP-1) secretion, using the GLUTag enteroendocrine cell line. Materials and methods GLP-1 release from GLUTag cells was measured in response to agents that increase cAMP, and single cells were studied by fluorescence calcium imaging and electrophysiology to evaluate the underlying pathways.

Results Pituitary adenylate cyclase-activating polypeptide increased cAMP levels and stimulated GLP-1 release from GLUTag cells. Agents that increase cAMP levels, including forskolin plus 3-isobutyl-1-methylxanthine (fsk/IBMX), triggered a rise in the intracellular calcium concentration and enhanced the response to glucose by increasing both the number of cells responding to glucose and the magnitude of calcium responses in individual cells. Importantly, fsk/IBMX also stimulated GLP-1 release and intracellular calcium elevation even in the absence of nutrients. fsk/IBMX triggered membrane depolarisation and the firing of action potentials, associated with a $+14 \mathrm{mV}$ shift in the voltage-dependence of activation of hyperpolarisation-activated currents and the closure of a background potassium conductance.

Conclusions/interpretation We show here that cAMP elevation directly triggers GLP-1 release and enhances the secretory response to other stimuli like glucose, by modulat-
\end{abstract}

A. K. Simpson and P. S. Ward contributed equally to this study.

A. K. Simpson · P. S. Ward · K. Y. Wong • G. J. Collord •

A. M. Habib · F. Reimann • F. M. Gribble $(\square)$

Cambridge Institute for Medical Research and Department

of Clinical Biochemistry, University of Cambridge, Wellcome

Trust/MRC Building, Addenbrooke's Hospital,

Hills Road, Cambridge CB2 0XY, UK

e-mail: fmg23@cam.ac.uk ing hyperpolarisation-activated currents and the background potassium current. cAMP-elevating pathways and the cAMPmodulated conductances in L cells present important targets for the development of therapeutic GLP-1 secretagogues.

Keywords Cyclic AMP. Gastro-entero pancreatic factors . Glucagon-like peptide-1 · GLUTag cells

$\begin{array}{ll}\text { Abbreviations } \\ {\left[\mathrm{Ca}^{2+}\right]_{\mathrm{i}}} & \text { intracellular calcium concentration } \\ \text { cAMP } & \text { cyclic AMP } \\ \text { CGRP } & \text { calcitonin gene-related peptide } \\ \text { EPAC } & \text { cAMP-guanine nucleotide exchange factor } \\ \text { fsk/IBMX } & \text { forskolin plus IBMX } \\ \text { GIP } & \text { glucose-dependent insulinotrophic peptide } \\ \text { GLP-1 } & \text { glucagon-like peptide-1 } \\ \text { IBMX } & \text { 3-isobutyl-1-methylxanthine } \\ I_{\mathrm{h}} & \text { hyperpolarisation-activated current } \\ \mathrm{K}_{\text {ATP }} & \begin{array}{l}\text { ATP-sensitive potassium channels } \\ \text { PACAP }\end{array} \\ & \begin{array}{l}\text { pituitary adenylate cyclase-activating } \\ \text { polypeptide }\end{array} \\ \text { PKA } & \text { protein kinase A }\end{array}$

\section{Introduction}

Glucagon-like peptide-1 (GLP-1) is an incretin hormone, secreted in response to food ingestion, which stimulates insulin release from the endocrine pancreas. Together with glucose-dependent insulinotrophic peptide (GIP), it is responsible for up to $50 \%$ of normal insulin release following a meal [1]. As incretin hormones enhance glucose-stimulated insulin release, but do not on their own initiate insulin secretion, their action in vivo is glucosedependent [2]. The new GLP-1-based glucose-lowering 
therapies, comprising GLP-1 analogues and agents that inhibit GLP-1 degradation, take advantage of this property to offer safer therapies for type 2 diabetes [3]. An alternative therapeutic strategy that is receiving increasing interest is to stimulate secretion of endogenous GLP-1 from intestinal L cells. As GLP-1 is co-secreted with the anorexigenic peptide, peptide $\mathrm{YY}$, and the intestinally trophic hormone, GLP-2, enhancing L cell secretion is also of potential interest for appetite control [4] and to enhance intestinal epithelial proliferation in certain gastroenterological disorders [5].

A critical step towards the identification of GLP-1 secretagogues is to understand the different pathways involved in L cell stimulation, their relative importance in vivo and their potential synergistic or antagonistic interactions. L cells are scattered over the villi and crypts of the intestine, from the level of the jejunum down to the rectum [6]. Although secretion of GLP-1 is known to be triggered by food ingestion, it remains unclear exactly which cell populations respond at different stages after a meal, and how important luminal and neural/hormonal signals are for secretion from the different cell populations [7]. A range of stimuli enhancing GLP-1 secretion have been identified in whole-animal studies [8], as well as in model systems such as perfused intestine [9], cultured fetal rat intestinal cells [10], partially purified adult canine L cells [11] and enteroendocrine cell lines such as GLUTag [12], STC-1 [13] and NCI-H716 [14]. These include nutrients (e.g. sugars, amino acids, peptones, fats), hormones (e.g. GIP, calcitonin generelated peptide [CGRP], gastrin-releasing peptide), and neurotransmitters (e.g. acetylcholine, $\gamma$-amino butyric acid) $[2,5,7]$.

Single-cell measurements of electrical activity and calcium concentrations have shown that secretion from $\mathrm{L}$ cells, as in other endocrine cells, is dependent on elevation of the intracellular calcium concentration $\left(\left[\mathrm{Ca}^{2+}\right]_{\mathrm{i}}\right)$, triggered by either membrane depolarisation and $\mathrm{Ca}^{2+}$ entry through voltage-gated $\mathrm{Ca}^{2+}$ channels or $\mathrm{Ca}^{2+}$ release from intracellular stores [14-17]. Our studies on GLUTag enteroendocrine cells have shown that glucose and amino acids (e.g. glutamine, alanine, glycine) trigger membrane depolarisation and the generation of action potentials in GLUTag cells, resulting in $\mathrm{Ca}^{2+}$ entry and the initiation of GLP-1 secretion [18-20].

Whereas many of the identified stimuli of GLP-1 secretion exhibit variable efficacy depending on the experimental preparation, elevation of cyclic AMP (cAMP) has been repeatedly found to release GLP-1 in a range of different studies $[11,14,15,21,22]$. A number of hormones and neurotransmitters that can activate adenylate cyclase have been identified in the enteric nervous system [23] and the intestinal epithelium, e.g. GIP, CGRP, pituitary adenylate cyclase-activating polypeptide (PACAP) and noradrenaline (norepinephrine). Of these, GIP, CGRP and $\beta$-adrenergic agonists have been shown to stimulate GLP-1 release [9, 24-26], suggesting that hormonal, paracrine and/ or neural circuits may play a role in regulating secretion from L cells. The first identified action of cAMP elevation on $\mathrm{L}$ cells was stimulation of proglucagon gene transcription [12]. This has been subsequently shown to involve both protein kinase A (PKA)-dependent and -independent pathways, the latter involving cAMP-guanine nucleotide exchange factors (EPACs) [27]. There is also evidence, however, that cAMP stimulates GLP-1 secretion as well as its synthesis [21]. In pancreatic beta cells, stimulation of insulin release by cAMP involves the glucose-dependent recruitment of previously unresponsive cells and amplification of the secretory pathway downstream of a calcium rise [28-30]. In GLUTag cells, however, we found that forskolin and 3-isobutyl-1-methylxanthine (fsk/IBMX) stimulated GLP-1 secretion in the absence as well as the presence of glucose [22]. The aim of this study was to investigate further the pathways underlying the stimulation of GLP-1 release by cAMP in GLUTag cells.

\section{Materials and methods}

Cell culture GLUTag cells were cultured in Dulbecco's modified Eagle's medium containing $5.5 \mathrm{mmol} / 1$ glucose, as described previously [22]. The GLUTag cell line was originally derived from a colonic tumour taken from a transgenic mouse expressing SV40 large T-antigen under the control of the proglucagon promoter [12], and has proved to be a reliable model of GLP-1 secretion as it exhibits sensitivity to a range of physiological stimuli.

GLP-1 secretion For secretion experiments, cells were plated in 24 well culture plates coated with Matrigel (BD Biosciences, Oxford, UK), and allowed to reach $60-80 \%$ confluence. On the day of the experiment, cells were washed twice with $500 \mu \mathrm{l}$ nutrient-free standard bath solution supplemented with $0.1 \mathrm{mmol} / 1$ diprotin A (IlePro-Ile) and $0.1 \%$ (wt/vol.) BSA. For experiments in $30 \mathrm{mmol} / \mathrm{l} \mathrm{KCl}$, the concentration of $\mathrm{NaCl}$ was reduced equivalently. Experiments were performed by incubating cells with test reagents in the same solution for $2 \mathrm{~h}$ at $37^{\circ} \mathrm{C}$. The final DMSO concentration was adjusted to $0.1 \%$ for all conditions, including controls. After the incubation period, medium was collected and centrifuged to remove any floating cells. GLP-1 was assayed using an ELISA specific for GLP-1(7-36) amide and GLP-1(7-37) (Linco GLP-1 active ELISA-kit; Biogenesis, Poole, UK).

cAMP measurements Cells in 24 well plates were treated as described for secretion experiments. Test agents were 
applied in $10 \mathrm{mmol} / \mathrm{l}$ glucose for $15 \mathrm{~min}$ at $37^{\circ} \mathrm{C}$ and cells were subsequently lysed for $10 \mathrm{~min}$ with $500 \mu \mathrm{l} /$ well $0.25 \%$ dodecyltrimethylammonium bromide in $50 \mathrm{mmol} / 1$ sodium acetate $(\mathrm{pH} 5.8)$ containing $0.02 \%(\mathrm{w} / \mathrm{v}) \mathrm{BSA}$ at room temperature. cAMP in the lysate was assayed by ELISA (GE Healthcare, Little Chalfont, UK) and cell lysis was confirmed using $0.1 \%$ Trypan Blue solution.

$\left[\mathrm{Ca}^{2+}\right]_{i}$ measurements Cells were plated in Matrigel-coated glass bottom dishes (MatTek, Ashland, MA, USA) 1-3 days prior to use and loaded with fura- 2 by incubation in $2 \mu \mathrm{mol} / 1$ of the acetoxymethylester (Molecular Probes, Leiden, the Netherlands) for $30 \mathrm{~min}$ in bath solution containing $1 \mathrm{mmol} / \mathrm{l}$ glucose at room temperature. Cells were then washed with bath solution, and the experiment started within $10 \mathrm{~min}$. Dishes were mounted on an inverted fluorescence microscope (Olympus IX71; Southall, UK) with a $\times 40$ oil-immersion objective. Excitation at 340 and $380 \mathrm{~nm}$ was achieved using a $75 \mathrm{~W}$ xenon arc lamp with a monochromator (Cairn Research, Faversham, UK) controlled by MetaFluor software (Universal Imaging; Cairn Research) and emission was recorded with a CCD camera (Orca ER, Hammamatsu; Cairn Research). Free cytoplasmic $\mathrm{Ca}^{2+}$ concentrations were estimated for individual cells from background-subtracted fluorescence using the equation of Grynkiewicz et al. [31] assuming a $K_{\mathrm{d}}$ of $224 \mathrm{nmol} / 1$ for fura-2. Minimal and maximal signals were recorded in the presence of $5 \mu \mathrm{mol} / \mathrm{l}$ ionomycin in $5 \mathrm{mmol} / \mathrm{l} \mathrm{EGTA} /$ $0 \mathrm{mmol} / \mathrm{l} \mathrm{Ca}^{2+}$ and $5 \mathrm{mmol} / \mathrm{C} \mathrm{Ca}^{2+}$, respectively, at the end of the experiment. In subsequent analysis, the background level for each cell was obtained by averaging $\left[\mathrm{Ca}^{2+}\right]_{\mathrm{i}}$ in control solution, and the response to test agents was defined as the maximum concentration (averaged over $20 \mathrm{~s}$ ) achieved during their application.

Electrophysiology Cells were plated into $35 \mathrm{~mm}$ dishes 1-3 days prior to use. Experiments were performed on single cells and well-defined cells in small clusters. Microelectrodes were pulled from borosilicate glass (GC150T; Harvard Apparatus, Edenbridge, UK) and the tips coated with refined yellow beeswax. Electrodes were fire-polished using a microforge (Narishige, London, UK) and had resistances of 2.5-3 $\mathrm{M} \Omega$ when filled with pipette solution. Membrane potential and currents were recorded using an Axopatch 200B (Axon Instruments, Union City, CA, USA) linked through a Digidata 1320A interface and pCLAMP software (Axon Instruments). Electrophysiological recordings were made using the perforated-patch configuration of the patch-clamp setup, at $22-24^{\circ} \mathrm{C}$.

Solutions and chemicals The perforated-patch pipette solution contained (mmol/l): $76 \mathrm{~K}_{2} \mathrm{SO}_{4}, 10 \mathrm{KCl}, 10 \mathrm{NaCl}, 55$ sucrose, $10 \mathrm{HEPES}$ and $1 \mathrm{MgCl}_{2}$, (pH 7.2 with $\left.\mathrm{KOH}\right)$, to which amphotericin $\mathrm{B}$ was added to a final concentration of $200 \mu \mathrm{g} / \mathrm{ml}$. The standard bath solution contained ( $\mathrm{mmol} / \mathrm{l}$ ): $5.6 \mathrm{KCl}, 138 \mathrm{NaCl}, 2.6 \mathrm{CaCl}_{2}, 1.2 \mathrm{MgCl}_{2}, 10$ HEPES (pH 7.4 with $\mathrm{NaOH}$ ). Calcium currents were recorded in bath solution containing (mmol/l): $5.6 \mathrm{CsCl}, 118 \mathrm{NaCl}, 2.6$ $\mathrm{CaCl}_{2}, 1.2 \mathrm{MgCl}_{2}, 10$ HEPES, 20 tetraethylammonium chloride (TEACl; $\mathrm{pH}$ 7.4) with the addition of $0.3 \mu \mathrm{mol} / 1$ tetrodotoxin (TTX). The perforated-patch solution for recording calcium currents contained (mmol/l): $76 \mathrm{Cs}_{2} \mathrm{SO}_{4}$, $10 \mathrm{KCl}, 10 \mathrm{NaCl}, 1 \mathrm{MgCl}_{2}$, 5 HEPES (pH 7.35 with $\mathrm{CsOH})$, to which amphotericin $\mathrm{B}$ was added to a final concentration of $200 \mu \mathrm{g} / \mathrm{ml}$.

Drugs and chemicals were purchased from Sigma-Aldrich (Poole, UK) unless otherwise stated. $\mathrm{CsCl}$ and $\mathrm{CsOH}$ were from Alfa Aesar (Avocado Research Chemicals, Heysham, UK). 6-Benzoyl cAMP and 8-CPT 2-O-methyl cAMP were purchased from Biolog (Bremen, Germany). ZD7288 was from Tocris (Avonmouth, Bristol, UK). Forskolin and IBMX were prepared as $1,000 \times$ stocks in DMSO.

$R T-P C R$ RT-PCR was performed as described previously [22] using the following specific primers, which were designed using sequence information from http://www. ensembl.org/mus_musculus/ (from $5^{\prime}$ to $3^{\prime}$ ): Epacl (also known as Rapgef3): 5'-GTGTGAGCTGGAGAAGAAAC-3' and 5'-GGAACCTGTAGAATTGGGC-3' (572 bp), Epac2: 5'-GCGATCTAGTGAAGATGTGG-3' and 5'-CTTAT CATGTGGGGAGCTC-3' (539 bp). The identity of positive bands in GLUTag cells was confirmed by direct sequencing.

Data analysis Data were analysed with Microcal Origin (Aston Scientific, Milton Keynes, UK), pClamp and Microsoft Excel software.

Calcium currents were fitted with a Boltzmann equation $y=$ $\left(A_{2}+\left[A_{1}-A_{2}\right] /\left(1+\exp \left(\left[V_{0.5}-V_{\mathrm{m}}\right] / k\right)\right)\right) \times\left(V_{\mathrm{m}}-V_{\text {rev }}\right)$, where $V_{\mathrm{m}}$ is the voltage, $A_{1}$ is the conductance of the calcium current, $A_{2}$ is the background conductance, $V_{0.5}$ is the halfmaximum voltage of activation, $k$ is a constant, and $V_{\text {rev }}$ is the reversal potential of the calcium current. Time constants of decay of the calcium current $(\tau)$ were fitted with a single exponential over the first $200 \mathrm{~ms}$ after the peak.

Hyperpolarisation-activated currents were fitted with a modified Boltzmann equation: $y=g_{\max \left(I_{\mathrm{h}}\right)} \times\left(V_{\mathrm{m}}+\right.$ $40) /\left(1+e^{\left(V_{\mathrm{m}}-V_{0.5}\right) / k}\right)+g_{\mathrm{b}} \times\left(V_{\mathrm{m}}-V_{\operatorname{rev}(\mathrm{b})}\right)$ where $g_{\max \left(I_{\mathrm{h}}\right)}$ is the maximum conductance of the $I_{\mathrm{h}}$ current, $V_{\mathrm{m}}$ is the membrane potential, $V_{0.5}$ is the half-maximum voltage of activation of $I_{\mathrm{h}}, k$ is a constant for $I_{\mathrm{h}}, g_{\mathrm{b}}$ is the conductance of the background current, and $V_{\text {rev(b) }}$ is the reversal potential of the background current.

Results are presented as means \pm SE. Statistical significance was tested by Student's one-sample, two-sample or paired $t$ test, as appropriate, using a threshold for significance of $p<0.05$. 


\section{Results}

A variety of hormones have been shown to trigger secretion from GLP-1-secreting cells, including some which, in other cell types, are known to couple to adenylate cyclase activation and cAMP formation. In GLUTag cells, GIP and PACAP dose-dependently triggered GLP-1 release in the presence of $10 \mathrm{mmol} / \mathrm{l}$ glucose, with a maximum stimulation of 1.8- to 2-fold, and approximate $\mathrm{EC}_{50}$ values of $7 \mathrm{nmol} / \mathrm{l}$ for GIP and $1 \mathrm{nmol} / 1$ for PACAP (Fig. 1). Similar stimulation of GLP-1 release from GLUTag cells by GIP has been demonstrated previously [21]. These responses compare with a fourfold stimulation by fsk/ IBMX $(10 \mu \mathrm{mol} / 1$ of each) in parallel experiments. PACAP has previously been shown to stimulate cholecystokinin and secretin release from another enteroendocrine cell line, STC-1, associated with a rapid increase in intracellular cAMP that was only detectable in the presence of IBMX [32]. In GLUTag cells, 15 min incubations with PACAP or GIP (both at $10^{-7} \mathrm{~mol} / \mathrm{l}$, at which maximum secretion was observed) elevated cAMP concentrations $\sim 1.5$ - to 2-fold in the presence of IBMX (Fig. 1b), but did not have detectable effects on cAMP levels in the absence of IBMX.

To investigate the actions of cAMP in further detail, we monitored calcium concentrations in GLUTag cells by measuring the $340: 380 \mathrm{~nm}$ fluorescence ratio in cells loaded with fura-2. PACAP $\left(10^{-7} \mathrm{~mol} / \mathrm{l}\right)$ increased the fluorescence ratio and enhanced the response to glucose in many cells (Fig. 2a). In further experiments to dissect the underlying mechanism, we used fsk/IBMX rather than PACAP to elevate cAMP. This triggered qualitatively similar responses in calcium imaging studies. Glucose triggered an elevation of $\left[\mathrm{Ca}^{2+}\right]_{\mathrm{i}}$ in 26 out of 40 cells (Fig. 2b,c), with a mean increment of $204 \pm 50 \mathrm{nmol} / 1(n=40$, $p<0.001)$. In the presence of fsk/IBMX, however, 40 out of 40 cells responded to glucose (mean increment $759 \pm 160 \mathrm{nmol} / \mathrm{l})$, and in 38 out of 40 cells glucose responsiveness was maintained $8-10 \mathrm{~min}$ after fsk/IBMX washout despite a return of the basal $\left[\mathrm{Ca}^{2+}\right]_{i}$ to resting levels (Fig. 2b,c; mean glucose-triggered increment $731 \pm 150 \mathrm{nmol} / 1, p<0.001$, vs response to first glucose application before fsk/IBMX). In the absence of glucose we also observed that fsk/IBMX itself triggered an increase in $\left[\mathrm{Ca}^{2+}\right]_{\mathrm{i}}$ in 51 out of 65 cells (Fig. 2d,e), with a mean increment of $288 \pm 37 \mathrm{nmol} / 1(n=65, p<0.001)$.

Similar results in pancreatic beta cells have been attributed to contributions from separate cAMP-dependent pathways involving EPAC and PKA [33]. By RT-PCR, we detected both EPAC1 and EPAC2, suggesting that this pathway might similarly operate in GLUTag cells (Fig. 3a). To attempt to distinguish whether EPAC and PKA mediate calcium responses to fsk/IBMX, we tested the effect of two membrane-permeant cAMP analogues: 6-benzoyl cAMP, a

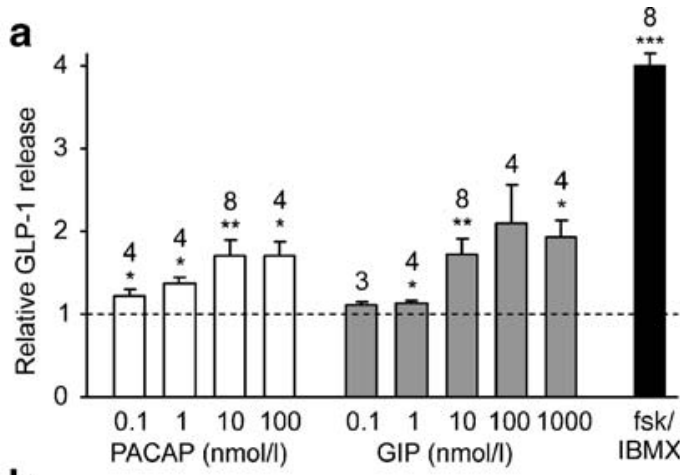

b

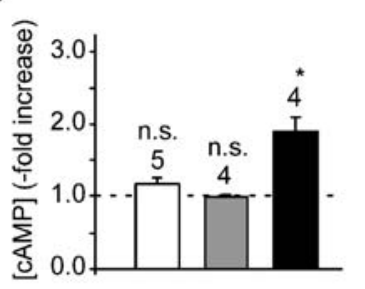

$\begin{array}{lccc}\operatorname{IBMX}(\mu \mathrm{mol} / \mathrm{l}) & - & - & - \\ \operatorname{PACAP}(\mathrm{nmol} / \mathrm{l}) & 100 & - & - \\ \operatorname{GIP}(\mathrm{nmol} / \mathrm{l}) & - & 100 & - \\ \text { fsk }(\mu \mathrm{mol} / \mathrm{l}) & - & - & 10\end{array}$

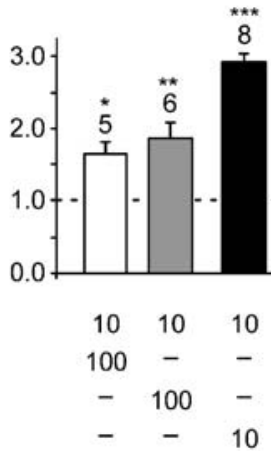

Fig. 1 Hormonal stimulation of GLP-1 release from GLUTag cells. a GLP-1 secretion from GLUTag cells incubated for $2 \mathrm{~h}$ with $10 \mathrm{mmol} / \mathrm{l}$ glucose plus the additions indicated: fsk/IBMX (10 $\mu \mathrm{mol} / 1$ of each), PACAP or GIP at different concentrations. Secretion was normalised to baseline secretion in $10 \mathrm{mmol} / 1$ glucose alone, measured in parallel on the same day (indicated by the dashed line). The dose-dependence of GLP-1 secretion triggered by GIP and PACAP was fitted using a logistic equation, with $\mathrm{EC}_{50}$ values of 7 and $1 \mathrm{nmol} / 1$, respectively. The number of wells is given above each bar. Statistical significance, comparing secretion in $10 \mathrm{mmol} / \mathrm{l}$ glucose with and without the test agent, was tested using Student's $t$ test, $* p<0.05, * * p<0.01, * * * p<$ 0.001. b cAMP concentrations in GLUTag cells incubated for $15 \mathrm{~min}$ with $10 \mathrm{mmol} / \mathrm{l}$ glucose plus the additions indicated: IBMX (10 $\mu \mathrm{mol} / \mathrm{l})$, PACAP $(100 \mathrm{nmol} / \mathrm{l})$, GIP $(100 \mathrm{nmol} / \mathrm{l})$ or fsk (10 $\mu \mathrm{mol} / 1)$. The measured cAMP concentration was normalised to that measured in control wells, containing either $10 \mathrm{mmol} / 1$ glucose alone (left-hand panel) or $10 \mathrm{mmol} / 1$ glucose plus IBMX (right-hand panel). IBMX did not significantly alter background cAMP levels in $10 \mathrm{mmol} / 1$ glucose. The number of wells is given above each bar. Statistical significance, comparing the fold-elevation of cAMP by test agents, was assessed by one-sample Student's $t$ test, $* p<0.05$, $* * p<0.01, * * * p<0.001$, n.s., not significant

relatively selective activator of PKA over EPAC, and 8-CPT 2-O-methyl cAMP, an activator of EPAC but not the PKA [34]. As shown in Fig. 3c, both 6-benzoyl cAMP and 8-CPT 2-O-methyl cAMP (both at $100 \mu \mathrm{mol} / \mathrm{l}$ ) triggered increases in $\left[\mathrm{Ca}^{2+}\right]_{\mathrm{i}}$ and enhanced the response to glucose. Whilst these findings suggest a possible role for EPAC and PKA, the data do not exclude the possibility that both cAMP and the analogues act on other cAMP-binding proteins such as ion channels. In secretion studies, however, the PKA inhibitor H89 (10 $\mu \mathrm{mol} / \mathrm{l})$ inhibited fsk/IBMXtriggered GLP-1 release by $\sim 25 \%$ (Fig. 3b), suggesting a role for PKA in cAMP-triggered GLP-1 release. 
a

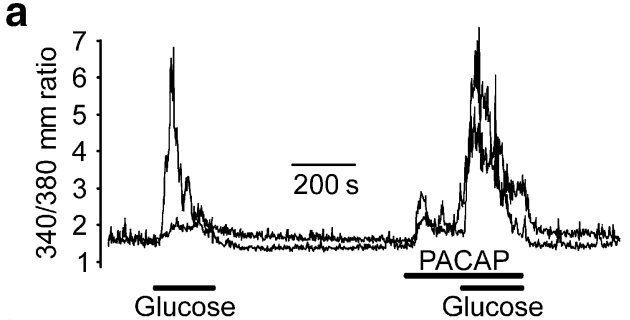

b

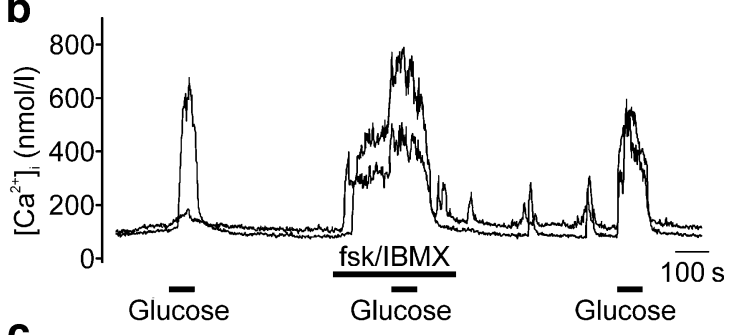

C

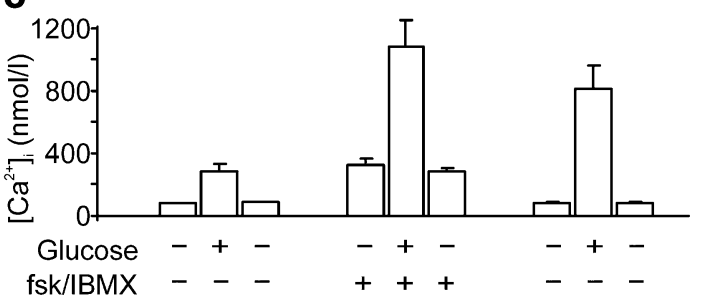

d

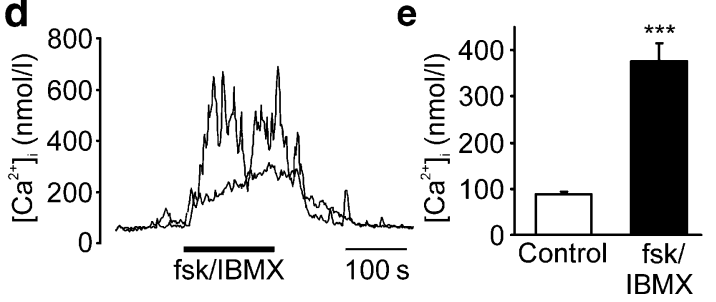

Fig. 2 Intracellular calcium responses to cAMP elevation. a $\left[\mathrm{Ca}^{2+}\right]_{\mathrm{i}}$, monitored as the ratio of fluorescence at 340 and $380 \mathrm{~nm}$, in two individual GLUTag cells loaded with fura-2. PACAP $\left(10^{-7} \mathrm{~mol} / \mathrm{l}\right)$ and glucose $(10 \mathrm{mmol} / \mathrm{l})$ were added as indicated by the horizontal bars. b Calibrated $\left[\mathrm{Ca}^{2+}\right]_{\mathrm{i}}$ in two single cells in response to $10 \mathrm{mmol} /$ 1 glucose and fsk/IBMX (10 $\mu \mathrm{mol} / \mathrm{l}$ of each), added as indicated by the horizontal bars. c Mean $\left[\mathrm{Ca}^{2+}\right]_{\mathrm{i}}$ averaged over $20 \mathrm{~s}$ periods for experiments carried out as in $\mathbf{b}(n=36-40$ cells from four separate experiments). Error bars indicate $1 \mathrm{SE} . \mathbf{d}\left[\mathrm{Ca}^{2+}\right]_{\mathrm{i}}$ in two single cells in response to fsk/IBMX $(10 \mu \mathrm{mol} / 1$ of each $)$, added as indicated by the horizontal bar in the absence of nutrient. e Mean $\left[\mathrm{Ca}^{2+}\right]_{\mathrm{i}}$ averaged over $20 \mathrm{~s}$ periods for experiments carried out as in $\mathbf{d}(n=65$ cells from six separate experiments). Error bars indicate 1 SE. ${ }^{* * *} p<0.001$ by Student's $t$ test

To evaluate the possible role of intracellular $\mathrm{Ca}^{2+}$ stores in fsk/IBMX-triggered GLP-1 release, we measured secretion following depletion of the endoplasmic reticulum $\mathrm{Ca}^{2+}$ stores using thapsigargin. Preincubation of GLUTag cells with $10 \mu \mathrm{mol} / 1$ thapsigargin did not impair responses to glucose or fsk/IBMX (data not shown), suggesting that the release of stored $\mathrm{Ca}^{2+}$ is not critical for cAMP-triggered GLP-1 release. By contrast, we showed previously that thapsigargin abolished GLP-1 secretion triggered by bombesin, which operates through inositol trisphosphate-mediated $\mathrm{Ca}^{2+}$ release [17].
Electrophysiological experiments were performed to investigate whether increasing the cAMP concentration affected the properties of the voltage-gated calcium current. In perforated-patch experiments, fsk/IBMX caused a modest, but non-significant, increase in the peak $\mathrm{Ca}^{2+}$ current of $12 \pm 5 \%$ (at $+10 \mathrm{mV}, n=4$ ), without affecting the voltage-dependence of activation $\left(V_{0.5}+1 \pm 5 \mathrm{mV}\right.$ in control vs $-2 \pm 3 \mathrm{mV}$ in fsk/IBMX, $n=4)$, or the time course of inactivation $(\tau$ at $+10 \mathrm{mV} 53 \pm 5 \mathrm{~ms}$ in control vs $56 \pm 2 \mathrm{~ms}$ in fsk/IBMX, $n=4$ ) (Fig. 4). In support of the idea that fsk/ IBMX does not significantly affect calcium currents in GLUTag cells, we also found by fluorescence imaging that the calcium increment triggered by $17 \mathrm{mmol} / 1 \mathrm{KCl}$ was not significantly different in the absence and presence of fsk/ IBMX (Fig. 4c, mean change in $\left[\mathrm{Ca}^{2+}\right]_{\mathrm{i}} 245 \pm 37 \mathrm{nmol} / \mathrm{l} \mathrm{vs}$ $282 \pm 32 \mathrm{nmol} / \mathrm{l}$, respectively).

An alternative explanation for the $\mathrm{Ca}^{2+}$ imaging results is that fsk/IBMX directly affects the membrane potential. To investigate this possibility, cells were monitored electrophysiologically in perforated-patch whole-cell recordings (Fig. 5) at low glucose concentrations $(0.2-1 \mathrm{mmol} / \mathrm{l})$.
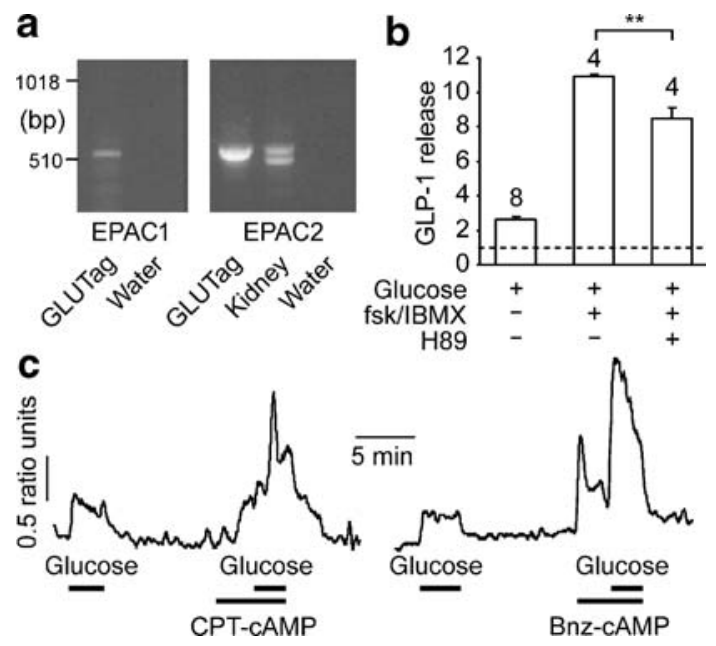

Fig. 3 EPAC- and PKA-dependent actions. a Expression of Epac1 and Epac2 in GLUTag cells, as determined by RT-PCR. The predicted band sizes are 572 and $539 \mathrm{bp}$, respectively. b GLP-1 secretion from GLUTag cells incubated for $2 \mathrm{~h}$ with $10 \mathrm{mmol} / 1$ glucose plus fsk/ IBMX $(10 \mu \mathrm{mol} / 1$ of each $)$ and $\mathrm{H} 89(10 \mu \mathrm{mol} / \mathrm{l})$ as indicated. Secretion was normalised to baseline secretion in the absence of glucose, measured in parallel on the same day (indicated by the dashed line). The number of wells is given above each bar. Statistical significance, comparing secretion in $10 \mathrm{mmol} / \mathrm{l}$ glucose plus fsk/ IBMX with and without H89, was evaluated using Student's $t$ test, ${ }^{* *} p<0.01 . \mathbf{c}\left[\mathrm{Ca}^{2+}\right]_{\mathrm{i}}$, monitored as the ratio of fluorescence at 340 and $380 \mathrm{~nm}$, in GLUTag cells loaded with fura-2. Glucose (10 mmol/l), 6benzoyl cAMP (Bnz-cAMP, $100 \mu \mathrm{mol} / \mathrm{l}$ ) and 8-CPT 2-O-methyl cAMP (CPT-cAMP, $100 \mu \mathrm{mol} / \mathrm{l}$ ) were added as indicated by the horizontal bars. The vertical scale bar represents a change in the fluorescence ratio of 0.5 . The mean of 15 cells from one experiment is shown for CPT-cAMP, and the mean of 19 cells is shown for BnzcAMP; these are representative of two and three experiments, respectively 
Addition of fsk/IBMX resulted in a mean membrane depolarisation of $+5.3 \pm 1.1 \mathrm{mV}(n=6, p<0.01)$ and an increase in the mean action potential frequency from $0.07 \pm 0.05$ to $0.4 \pm 0.1 \mathrm{~Hz}(n=6, p<0.05)$.

To examine the nature of the underlying depolarising currents, we studied the cells in voltage clamp. As we have previously shown that GLUTag cells express hyperpolarisation activated channels [16], which are known to be modulated by cAMP in other tissues, we first used a voltage protocol suitable for $I_{\mathrm{h}}$ measurements. $I_{\mathrm{h}}$ currents were triggered by holding cells at $-40 \mathrm{mV}$, and stepping for $2 \mathrm{~s}$ to sequentially more hyperpolarised potentials (Fig. 5b). Following addition of fsk/IBMX, $I_{\mathrm{h}}$ appeared at more depolarised potentials and showed a more rapid rate of activation (Fig. $5 \mathrm{c}, \mathrm{d}$ ). The voltage at which $I_{\mathrm{h}}$ currents were half-maximally activated was shifted from $-85.7 \pm 1.9 \mathrm{mV}$ to $-72.1 \pm 1.7 \mathrm{mV}(n=6, p<0.001)$, without any change in the maximum conductance.
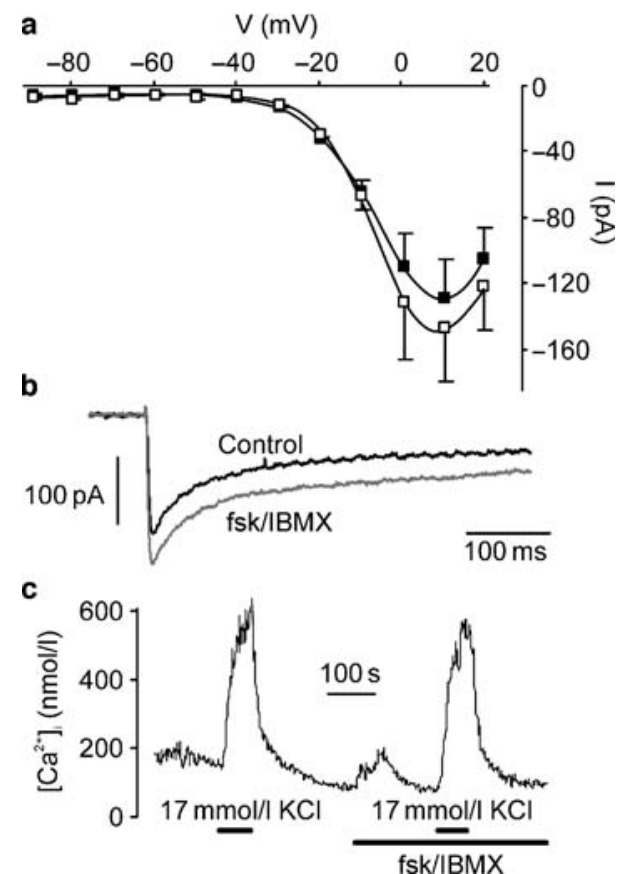

Fig. 4 Voltage-gated calcium currents. a Voltage-dependence of the peak calcium current in response to voltage steps to the different potentials shown from a holding potential of $-70 \mathrm{mV}$ in perforatedpatch experiments. Current (I)-voltage (V) relationships are shown in the absence (closed squares) and presence (open squares) of fsk/ $\operatorname{IBMX}(10 \mu \mathrm{mol} / 1$ of each). Error bars represent $1 \mathrm{SE}(n=4)$. The line shows a fit of the data with a Boltzmann equation $y=\left(A_{2}+\right.$ $\left.\left[A_{1}-A_{2}\right] /\left(1+\exp \left(\left[V_{0.5}-V_{\mathrm{m}}\right] / k\right)\right)\right) \times\left(V_{\mathrm{m}}-V_{\text {rev }}\right)$, with the following values in the absence and presence of fsk/IBMX, respectively: $A_{1} 6.1,4.9 \mathrm{nS} ; A_{2} 0.05,0.06 \mathrm{nS} ; V_{0.5}+2.1,-1.5 \mathrm{mV} ; k 8.7,7.1$; $V_{\text {rev }}+40,+46 \mathrm{mV}$. b Representative traces showing the current response to a voltage step from -70 to $+10 \mathrm{mV}$, in the absence and presence of fsk/IBMX. c Calibrated $\left[\mathrm{Ca}^{2+}\right]_{\mathrm{i}}$ in a GLUTag cell loaded with fura-2, and stimulated by $17 \mathrm{mmol} / 1 \mathrm{KCl}$ and/or fsk/IBMX $(10 \mu \mathrm{mol} / 1$ of each), as indicated by the horizontal bars
To investigate whether the activation of $I_{\mathrm{h}}$ by cAMP underlies the responsiveness of GLUTag cells to fsk/IBMX, we tested the effect of ZD7288, which blocks $\sim 70 \%$ of the $I_{\mathrm{h}}$ current in GLUTag cells at a concentration of $10 \mu \mathrm{mol} / 1$ [16]. In secretion studies, $100 \mu \mathrm{mol} / 1$, but not $10 \mu \mathrm{mol} / 1$, ZD7288 significantly inhibited fsk/IBMX-triggered GLP-1 release (Fig. 6a). In electrophysiological experiments, fsk/IBMX still triggered membrane depolarisation of $+4.8 \pm 0.9 \mathrm{mV}$ in the presence of $10 \mu \mathrm{mol} / 1 \mathrm{ZD} 7288 \quad(n=9$; not significantly different from the depolarisation of $5.3 \mathrm{mV}$ in the absence of ZD7288) and the firing of action potentials (Fig. 6b), consistent with the incomplete block of secretion by ZD7288. To investigate whether residual $I_{\mathrm{h}}$ currents could explain the depolarisation observed in ZD7288, we recorded the response to a series of voltage ramps from -90 to $-40 \mathrm{mV}$ before and after fsk/IBMX application in the continued presence of

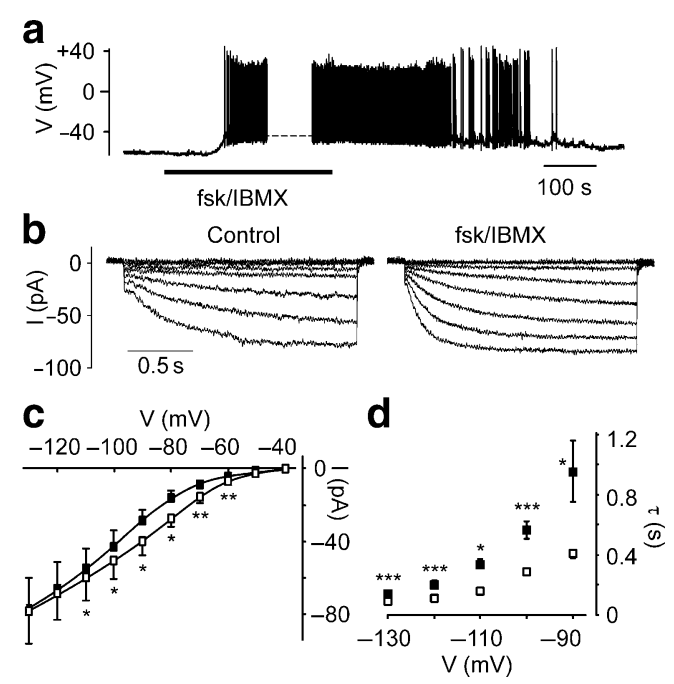

Fig. 5 Hyperpolarisation-activated channels. a Membrane potential of a single GLUTag cell monitored in a perforated-patch experiment. The cell was maintained in $0.2 \mathrm{mmol} / 1$ glucose, and fsk/IBMX (10 $\mu \mathrm{mol} / 1$ of each) added as shown by the horizontal bar. The gap represents a period of $\sim 2$ min, during which the cell was switched to voltage clamp. b Current (I) responses to $2,000 \mathrm{~ms}$ voltage steps of $-10 \mathrm{mV}$ increments (from $-40 \mathrm{mV}$ to $-110 \mathrm{mV}$ ) from a holding potential of $-40 \mathrm{mV}$, in a perforated-patch voltage-clamp recording applied at $\sim 0.25 \mathrm{~Hz}$. The same cell was recorded in control solution containing $1 \mathrm{mmol} / \mathrm{l}$ glucose (left) and in the additional presence of fsk/IBMX (right). c Currentvoltage relationship of the mean current at the end of voltage steps recorded as in $\mathbf{b}$, in the absence (closed squares) and presence (open squares) of fsk/IBMX. Error bars represent $1 \mathrm{SE}(n=5)$. The lines show fits of the data with a modified Boltzmann equation: $y=$ $g_{\max \left(I_{\mathrm{h}}\right)} \times\left(V_{\mathrm{m}}+40\right) /\left(1+e^{\left(V_{\mathrm{m}}-V_{0.5}\right) / k}\right)+g_{\mathrm{b}} \times\left(V_{\mathrm{m}}-V_{\text {rev(b) })}\right)$, with the following values, in the absence and presence of fsk/IBMX, respectively: $g_{\max \left(I_{\mathrm{h}}\right)} 0.69,0.74 \mathrm{nS} ; V_{0.5}-86,-69 \mathrm{mV} ; k 10.9,9.9 ; g_{\mathrm{b}}$ $0.17,0.12 \mathrm{nS} ; V_{\operatorname{rev}(\mathrm{b})}-39,-34 \mathrm{mV}$. ${ }^{*} p<0.05,{ }^{*} p<0.01$ by paired $t$ test. d Voltage-dependence of the time constant of activation of $I_{\mathrm{h}}$. Current traces obtained as in $\mathbf{b}$ at different voltages were fitted with a single exponential of time constant $\tau$. Control, filled squares; fsk/ IBMX, open squares $(n=5-6)$. Error bars represent 1 SE. Statistical significance, comparing $\tau$ in the absence and presence of fsk/IBMX at each voltage, was tested using Student's $t$ test, ${ }^{*} p<0.05,{ }^{* * *} p<0.001$ 
a
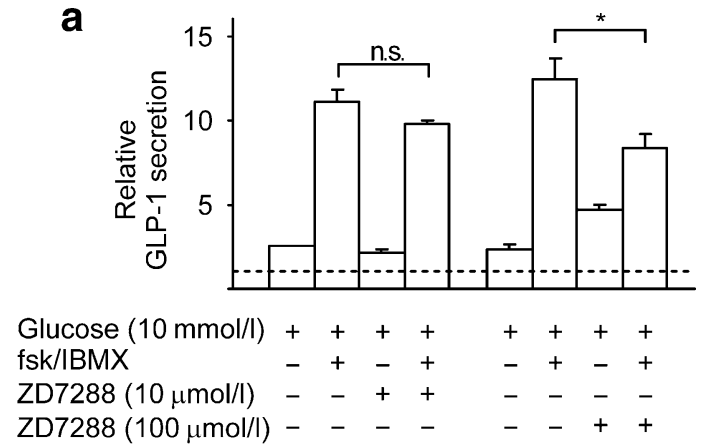

b

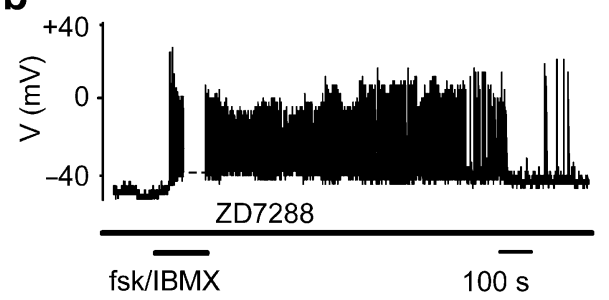

C

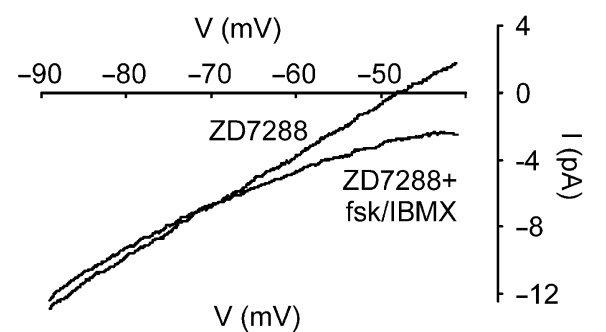

d

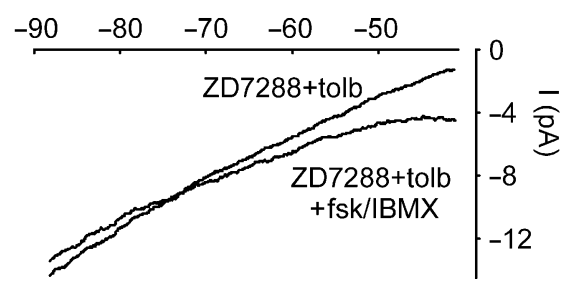

$10 \mu \mathrm{mol} / 1 \mathrm{ZD} 7288$. Under these conditions, we observed that fsk/IBMX inhibited a current that reversed at about $-70 \mathrm{mV}$ (Fig. 6c), close to the reversal potential of $\mathrm{K}^{+}$ions.

As GLUTag cells contain functional ATP-sensitive potassium $\left(\mathrm{K}_{\mathrm{ATP}}\right)$ channels, which are modulated by agents that increase cAMP in pancreatic beta cells [29], we examined the effect of fsk/IBMX in the presence of both ZD7288 and the $\mathrm{K}_{\mathrm{ATP}}$ channel inhibitor, tolbutamide $(500 \mu \mathrm{mol} / \mathrm{l})$. Under these conditions we still observed the inhibition by fsk/IBMX of a conductance reversing at about $-70 \mathrm{mV}$ (Fig. 6d), suggesting that this is a $\mathrm{K}^{+}$current distinct from $\mathrm{K}_{\text {ATP. }}$ Overall the results suggest that elevation of cAMP triggers membrane depolarisation in GLUTag cells as a consequence of both activation of $I_{\mathrm{h}}$ currents and inhibition of a background $\mathrm{K}^{+}$conductance.

To investigate whether cAMP also enhances secretion downstream of membrane depolarisation, we tested the effect of fsk/IBMX in GLUTag cells depolarised with $30 \mathrm{mmol} / \mathrm{K} \mathrm{KCl}$ plus $340 \mu \mathrm{mol} / \mathrm{l}$ diazoxide, which produces
Fig. 6 Effect of fsk/IBMX following $I_{\mathrm{h}}$ inhibition. a GLP-1 secretion from GLUTag cells incubated for $2 \mathrm{~h}$ with $10 \mathrm{mmol} / \mathrm{l}$ glucose plus fsk/ IBMX $(10 \mu \mathrm{mol} / 1$ of each) and ZD7288 at the concentrations indicated. Secretion was normalised to baseline secretion (indicated by the dashed line) in the absence of stimuli, measured in parallel on the same day (error bars represent $1 \mathrm{SE} ; n=3$ wells each). ${ }^{*} p<0.05$, $\mathrm{n}$. s., non-significant by Student's $t$ test. b Membrane potential of a single GLUTag cell monitored in a perforated-patch experiment. The cell was maintained in $0.2 \mathrm{mmol} / 1$ glucose plus $10 \mu \mathrm{mol} / 1 \mathrm{ZD} 7288$, and fsk/IBMX (10 $\mu \mathrm{mol} / 1$ of each) added as shown by the horizontal bar. The gap represents a period of $\sim 2 \mathrm{~min}$, during which the cell was switched to voltage clamp. c Current (I)-voltage (V) relationships for the conductance remaining in the presence of ZD7288 $(10 \mu \mathrm{mol} / \mathrm{l})$ before and following addition of fsk/IBMX (10 $\mu \mathrm{mol} / \mathrm{l}$ of each). Currents were triggered by repeatedly ramping the voltage over $2 \mathrm{~s}$ from -90 to $-40 \mathrm{mV}$, from a holding potential of $-70 \mathrm{mV}$. Twenty ramps were averaged in each condition. The data show the mean result from seven cells. d As in $\mathbf{c}$, in the additional presence of $500 \mu \mathrm{mol} / 1$ tolbutamide (tolb). The data show the mean result from three cells

a robust elevation of $\left[\mathrm{Ca}^{2+}\right]_{\mathrm{i}}$. Under these conditions, in the absence of glucose, fsk/IBMX still stimulated secretion $2.3 \pm 0.2$-fold $(n=4)$. This is likely to reflect an action of cAMP downstream of $\mathrm{Ca}^{2+}$ entry, as calcium currents were not affected by fsk/IBMX (Fig. 4). In beta cells, a similar potentiating effect of cAMP has been reported but is glucose-dependent [30].

\section{Discussion}

Elevation of cytoplasmic cAMP is a well-recognised stimulus of GLP-1 secretion in a variety of model systems, including perfused intestine, cultured fetal and adult intestinal cells and cell lines such as GLUTag and STC-1 $[11,14,15,21]$. Although previously shown to increase transcription of the proglucagon gene through PKAdependent and EPAC-dependent pathways [12, 27], there is also evidence that cAMP elevation directly enhances secretion [22]. We show here that cAMP acts as both a trigger and a potentiator of GLP-1 release from the GLUTag cell line, and that the triggering pathway involves the modulation of ion channel activity in the plasma membrane, leading to membrane depolarisation and action potential generation. The strong depolarising action of cAMP in the GLUTag cell may explain how fsk/IBMX triggers GLP-1 release from GLUTag cells even in the absence of added nutrient.

Two cAMP-sensitive conductances were identified electrophysiologically in GLUTag cells, which were distinct from those identified in studies on pancreatic beta cells [29]. We have previously shown that GLUTag cells express hyperpolarisation-activated channels, which are known to be modulated by cAMP in other cell types [35]. In resting GLUTag cells, with a membrane potential of -40 to $-50 \mathrm{mV}$, the $I_{\mathrm{h}}$ current is negligible. However, fsk/IBMX 
shifted the voltage-dependence of $I_{\mathrm{h}}$ activation by $\sim 14 \mathrm{mV}$, which would induce a depolarising $I_{\mathrm{h}}$ current of $\sim 0.5 \mathrm{pA}$ at $-50 \mathrm{mV}$. Although very small, this would be sufficient to trigger a depolarisation of a few $\mathrm{mV}$ in a GLUTag cell with a typical membrane resistance of $5 \mathrm{G} \Omega$. In other cell types, $I_{\mathrm{h}}$ has been shown to modulate action potential frequency and pacemaker activity, as it is activated during the hyperpolarisation that follows an action potential [35]. Inhibiting $I_{\mathrm{h}}$ in GLUTag cells with ZD7288 did not prevent membrane depolarisation triggered by fsk/IBMX, and relatively high concentrations were needed to impair fsk/ IBMX-triggered GLP-1 secretion. At such high concentrations, the specificity of ZD7288 must be questioned as it has been shown to inhibit exocytosis directly [36], although a generalised inhibition of exocytosis by $100 \mu \mathrm{mol} / \mathrm{Z}$ ZD7288 in our experiment seems unlikely, as it increased rather than reduced the background secretion in $10 \mathrm{mmol} / \mathrm{l}$ glucose. The maintained depolarising effect of fsk/IBMX in the presence of ZD7288, however, suggests that modulation of $I_{\mathrm{h}}$, whilst possibly contributing to the effect of fsk/IBMX in GLUTag cells, does not fully explain the results.

In the presence of ZD7288, we found that fsk/IBMX also inhibited a small current with a reversal potential of about $-70 \mathrm{mV}$, probably therefore reflecting a $\mathrm{K}^{+}$flux. This was distinct from $\mathrm{K}_{\mathrm{ATP}}$, as it was not abolished by tolbutamide. Examination of the current-voltage relationships in Fig. 6c,d suggests that this conductance exhibits outward rectification, although the appearance of outward rectification could also be generated by an additional small ZD7288-resistant $I_{\mathrm{h}}$ current appearing at more negative potentials. The identity of this $\mathrm{K}^{+}$current remains unknown, but possible candidates are members of the two-pore $\mathrm{K}^{+}$channel family, such as TREK-1, which we have shown previously to be expressed in GLUTag cells by Affymetrix microarray analysis [16]. TREK-1 and TREK-2 (which was not represented on the original Affymetrix chip) are inhibited by cAMP via PKA and exhibit outward rectification in physiological solutions [37].

The finding that cAMP modulates the activity of ion channels in GLUTag cells makes it difficult to interpret fully the cAMP analogue data. Our data suggest that PKA plays a role in fsk/IBMX-triggered secretion as the calcium changes were mimicked by 6-benzoyl cAMP, and H89 reduced GLP-1 release in the presence of fsk/IBMX. It is less clear, however, whether EPAC contributes to cAMP-triggered secretion. Although 8-CPT 2-O-methyl cAMP triggered changes in $\left[\mathrm{Ca}^{2+}\right]_{\mathrm{i}}$, we cannot exclude the possibility that this analogue also targets cAMP-binding sites on ion channels.

In calcium imaging experiments, we observed that as well as triggering an increase in $\left[\mathrm{Ca}^{2+}\right]_{\mathrm{i}}$, fsk/IBMX and PACAP enhanced the response to glucose by increasing both the number of active cells and the magnitude of responses in individual cells. Activation of voltage-gated
$\mathrm{Ca}^{2+}$ channels is unlikely to underlie these effects, as the calcium currents were not significantly affected by fsk/ IBMX. The effects on $\left[\mathrm{Ca}^{2+}\right]_{i}$ could, however, be explained by the depolarising action of cAMP. The small $I_{\mathrm{h}}$ current and reduced background $\mathrm{K}^{+}$conductance would tend to make the cells more excitable and enhance responses to other depolarising stimuli, such as those induced by nutrients.

Previous studies in GLUTag cells have shown that elevation of $\left[\mathrm{Ca}^{2+}\right]_{i}$ is essential for exocytosis, indicating that agents that only enhance the secretory response downstream of the calcium signal or stimulate proglucagon gene transcription would be ineffective without an additional trigger that stimulates either $\mathrm{Ca}^{2+}$ entry or $\mathrm{Ca}^{2+}$ release from stores. We showed previously that a calcium signal can be initiated in GLUTag cells by nutrients such as glucose and glutamine, or by activation of ionotrophic $\gamma$-amino butyric acid or glycine receptors [18-20,22]. We show here that hormones elevating cAMP may also initiate an increase in $\left[\mathrm{Ca}^{2+}\right]_{\mathrm{i}}$.

The nutrient-independent ability of cAMP to trigger electrical activity and potentiate secretion from GLUTag cells contrasts with the glucose-dependence of its actions on the pancreatic beta cell $[28,30]$. Physiologically, the glucose-dependence of beta cell function is essential to ensure that insulin release is not stimulated when glucose concentrations are low, with the consequent risk of hypoglycaemia. In $\mathrm{L}$ cells, by contrast, an ability of adenylate cyclase-coupled hormones and neurotransmitters to trigger GLP-1 release in the absence of nutrient could provide a pathway for the indirect stimulation of $\mathrm{L}$ cells lower in the gut, where levels of luminal nutrients are low. Further evaluation of the effects of cAMP elevation in vivo will require careful experiments, as the majority of anaesthetic agents affect ion channels and receptors that are produced in either the enteric nervous system or L cells. However, our results, taken together with the previous literature, suggest that targeting receptors on L cells coupled to adenylate cyclase could provide a therapeutic strategy to stimulate GLP-1 release in vivo.

Acknowledgements F. M. Gribble is a Wellcome Trust Senior Research Fellow, F. Reimann is the Meres Research Associate at St John's College, Cambridge, and P. S. Ward is a Churchill Scholar. We also thank D. Drucker (Toronto) for permission to work with GLUTag cells.

Duality of interest The authors declare that there is no duality of interest associated with this manuscript.

\section{References}

1. Nauck M, Stockmann F, Ebert R, Creutzfeldt W (1986) Reduced incretin effect in type 2 (non-insulin-dependent) diabetes. Diabetologia 29:46-52 
2. Holst JJ (2006) Glucagon-like peptide-1: from extract to agent. The Claude Bernard Lecture, 2005. Diabetologia 49:253-260

3. Drucker DJ, Nauck MA (2006) The incretin system: glucagon-like peptide-1 receptor agonists and dipeptidyl peptidase- 4 inhibitors in type 2 diabetes. Lancet 368:1696-1705

4. Wynne K, Bloom SR (2006) The role of oxyntomodulin and peptide tyrosine-tyrosine (PYY) in appetite control. Nat Clin Pract Endocrinol Metab 2:612-620

5. Estall JL, Drucker DJ (2006) Glucagon-like peptide-2. Annu Rev Nutr 26:391-411

6. Eissele R, Goke R, Willemer S et al (1992) Glucagon-like peptide-1 cells in the gastrointestinal tract and pancreas of rat, pig and man. Eur J Clin Invest 22:283-291

7. Deacon CF (2005) What do we know about the secretion and degradation of incretin hormones? Regulatory Pept 128:117-124

8. Herrmann C, Goke R, Richter G, Fehmann HC, Arnold R, Goke B (1995) Glucagon-like peptide-1 and glucose-dependent insulinreleasing polypeptide plasma levels in response to nutrients. Digestion 56:117-126

9. Plaisancie P, Bernard C, Chayvialle JA, Cuber JC (1994) Regulation of glucagon-like peptide-1-(7-36) amide secretion by intestinal neurotransmitters and hormones in the isolated vascularly perfused rat colon. Endocrinology 135:2398-2403

10. Brubaker PL, Vranic M (1987) Fetal rat intestinal cells in monolayer culture: a new in vitro system to study the glucagonlike immunoreactive peptides. Endocrinology 120:1976-1985

11. Damholt AB, Buchan AM, Kofod H (1998) Glucagon-likepeptide-1 secretion from canine L-cells is increased by glucosedependent-insulinotropic peptide but unaffected by glucose. Endocrinology 139:2085-2091

12. Drucker DJ, Jin T, Asa SL, Young TA, Brubaker PL (1994) Activation of proglucagon gene transcription by protein kinase-A in a novel mouse enteroendocrine cell line. Mol Endocrinol 8:1646-1655

13. Rindi G, Grant SG, Yiangou Y et al (1990) Development of neuroendocrine tumors in the gastrointestinal tract of transgenic mice. Heterogeneity of hormone expression. Am J Pathol 136:1349-1363

14. Reimer RA, Darimont C, Gremlich S, Nicolas-Metral V, Ruegg UT, Mace K (2001) A human cellular model for studying the regulation of glucagon-like peptide-1 secretion. Endocrinology 142:4522-4528

15. Brubaker PL (1988) Control of glucagon-like immunoreactive peptide secretion from fetal rat intestinal cultures. Endocrinology 123:220-226

16. Reimann F, Maziarz M, Flock G, Habib AM, Drucker DJ, Gribble FM (2005) Characterization and functional role of voltage gated cation conductances in the glucagon-like peptide-1 secreting GLUTag cell line. J Physiol 563:161-175

17. Reimann F, Ward PS, Gribble FM (2006) Signaling mechanisms underlying the release of glucagon-like peptide 1. Diabetes 55 (Suppl 2):S78-S85

18. Gribble FM, Williams L, Simpson AK, Reimann F (2003) A novel glucose-sensing mechanism contributing to glucagon-like peptide-1 secretion from the GLUTag cell line. Diabetes 52:1147-1154

19. Reimann F, Williams L, da Silva Xavier G, Rutter GA, Gribble FM (2004) Glutamine potently stimulates glucagon-like peptide-1 secretion from GLUTag cells. Diabetologia 47:1592-1601
20. Gameiro A, Reimann F, Habib AM et al (2005) The neurotransmitters glycine and GABA stimulate glucagon-like peptide-1 release from the GLUTag cell line. J Physiol 569:761-772

21. Brubaker PL, Schloos J, Drucker DJ (1998) Regulation of glucagon-like peptide-1 synthesis and secretion in the GLUTag enteroendocrine cell line. Endocrinology 139:4108-4114

22. Reimann F, Gribble FM (2002) Glucose-sensing in glucagon-like peptide-1-secreting cells. Diabetes 51:2757-2763

23. Furness JB (2000) Types of neurons in the enteric nervous system. J Auton Nerv Syst 81:87-96

24. Brubaker PL (1991) Regulation of intestinal proglucagon-derived peptide secretion by intestinal regulatory peptides. Endocrinology 128:3175-3182

25. Dumoulin V, Dakka T, Plaisancie P, Chayvialle JA, Cuber JC (1995) Regulation of glucagon-like peptide-1-(7-36) amide, peptide YY, and neurotensin secretion by neurotransmitters and gut hormones in the isolated vascularly perfused rat ileum. Endocrinology 136:5182-5188

26. Hansen L, Holst JJ (2002) The effects of duodenal peptides on glucagon-like peptide-1 secretion from the ileum. A duodeno-ileal loop? Regul Pept 110:39-45

27. Lotfi S, Li Z, Sun J, Zuo Y et al (2006) Role of the exchange protein directly activated by cyclic adenosine $5^{\prime}$-monophosphate (Epac) pathway in regulating proglucagon gene expression in intestinal endocrine L cells. Endocrinology 147:3727-3736

28. Holz GG, Habener JF (1992) Signal transduction crosstalk in the endocrine system: pancreatic beta-cells and the glucose competence concept. Trends Biochem Sci 17:388-393

29. Gromada J, Holst JJ, Rorsman P (1998) Cellular regulation of islet hormone secretion by the incretin hormone glucagon-like peptide 1 . Pflugers Arch 435:583-594

30. Yajima H, Komatsu M, Schermerhorn $T$ et al (1999) cAMP enhances insulin secretion by an action on the ATP-sensitive $\mathrm{K}^{+}$ channel-independent pathway of glucose signaling in rat pancreatic islets. Diabetes 48:1006-1012

31. Grynkiewicz G, Poenie M, Tsien RY (1985) A new generation of $\mathrm{Ca}^{2+}$ indicators with greatly improved fluorescence properties. J Biol Chem 260:3440-3450

32. Chang CH, Chey WY, Braggins L, Coy DH, Chang TM (1996) Pituitary adenylate cyclase-activating polypeptide stimulates cholecystokinin secretion in STC-1 cells. Am J Physiol 271:G516G523

33. Holz GG (2004) Epac: a new cAMP-binding protein in support of glucagon-like peptide-1 receptor-mediated signal transduction in the pancreatic beta-cell. Diabetes 53:5-13

34. Christensen AE, Selheim F, de Rooij J et al (2003) cAMP analog mapping of Epac1 and cAMP kinase. Discriminating analogs demonstrate that Epac and cAMP kinase act synergistically to promote PC-12 cell neurite extension. J Biol Chem 278:35394-35402

35. Kaupp UB, Seifert R (2001) Molecular diversity of pacemaker ion channels. Annu Rev Physiol 63:235-257

36. Gonzalez-Iglesias AE, Kretschmannova K, Tomic M, Stojilkovic SS (2006) ZD7288 inhibits exocytosis in an HCN-independent manner and downstream of voltage-gated calcium influx in pituitary lactotrophs. Biochem Biophys Res Commun 346:845-850

37. Patel AJ, Honore E, Maingret $F$ et al (1998) A mammalian two pore domain mechano-gated S-like $\mathrm{K}^{+}$channel. EMBO J $17: 4283-4290$ 